\title{
EVALUATION OF SHORELINE STABILIZATION USING A HYBRID SHORELINE MORPHOLOGY MODEL
}

\author{
Michael B. Kabiling, Taylor Engineering, Inc., mkabiling@taylorengineering.com \\ Michael E. Trudnak, Taylor Engineering, Inc., mtrudnak@taylorengineering.com \\ Richard Bouchard, St. Lucie County Erosion District, bouchardr@stlucieco.org
}

\section{INTRODUCTION}

The Fort Pierce Shore Protection Project, located in St. Lucie County, Florida, nourishes a 2.09-km Atlantic Ocean shoreline south of Fort Pierce Inlet on Florida's east coast. After each beach nourishment, historical measurements indicate the beach fill erodes nonuniformly, with a hotspot along the northernmost $0.7 \mathrm{~km}$ requiring nourishment after about two years of normal wave regimes. However, storms can quickly erode the beach fill and require nourishment earlier than the normal two-year interval. Longshore transport carries most of the eroded fill to the south, creating a strong feeder-beach effect. This study evaluated several designs and combinations of coastal structures to produce more uniform erosion throughout the project area and to increase the nourishment interval. The study applied several state-of-the-art numerical models to evaluate the two-dimensional effect of a "coastal structures" alternative on hydrodynamics, waves, sediment transport, and beach morphology.

\section{NUMERICAL MODELING}

This study applied previously validated MIKE21 Flexible Mesh (FM) hydrodynamic (HD), wave (SW), sediment transport (ST) models and a newly-developed hybrid shoreline morphology (SM) model to simulate water surface elevation, flow velocity, sediment (sand) transport, erosion, deposition, and shoreline movement in the area of interest. As simulations of long-term (multi-year) sediment transport and morphology with 2-D models require enormous computational resources and long computational time, this study applied effective wave and tide conditions that represented the offshore wave conditions and corresponding tide levels for the HD, SW, ST, and SM model simulations. A calibrated MIKE Littoral Processes (LP) one-line theory longshore transport model (see Table 1) provided the means to estimate multi-year longshore transport and long-term southward-directed net longshore transport at north and south of Ft. Pierce Inlet and estimate the effective wave and tide conditions offshore. LP model input consisted of available sediment, bathymetric, topographic, U.S. Army Corps of Engineers (USACE) Wave Information Study hindcasted waves, and National Oceanic and Atmospheric Administration (NOAA) predicted tides data.

Table 1 - Measured sediment budget and calibrated LP model net longshore transport rates at select locations

\begin{tabular}{|c|c|c|c|}
\hline Monument & $\begin{array}{c}\text { Sediment } \\
\text { Budget } \\
\left(\mathbf{m}^{3} / \mathrm{yr}\right)\end{array}$ & $\begin{array}{c}\text { LP Model } \\
\text { Calculated } \\
\left(\mathrm{m}^{3} / \mathrm{yr}\right)\end{array}$ & $\begin{array}{c}\text { Percent } \\
\text { Difference }\end{array}$ \\
\hline $\mathrm{R}-11$ & 175,848 & 199,251 & $13 \%$ \\
\hline $\mathrm{R}-41$ & 123,093 & 128,420 & $4 \%$ \\
\hline $\mathrm{R}-55$ & 172,789 & 170,706 & $-1 \%$ \\
\hline
\end{tabular}

Figure 1 shows good agreement in the LP model calculated cross-shore variations of the longshore transports for the full time series of waves and the selected representative waves for the calibration period (one year after the 2007 beach nourishment or July 1, 2007 - June
$30,2008)$ and a similar good comparison was also observed for the verification period (one year after the 2004 beach nourishment or July 1, 2004 - June 30, 2005). The good agreement in the cross-shore variations of the longshore transports between the full time series of waves and the selected representative waves indicates the selected representative waves produce comparable net longshore transport as the full time series of waves and therefore the representative waves can substitute for the full time series of waves to shorten the model computation time.

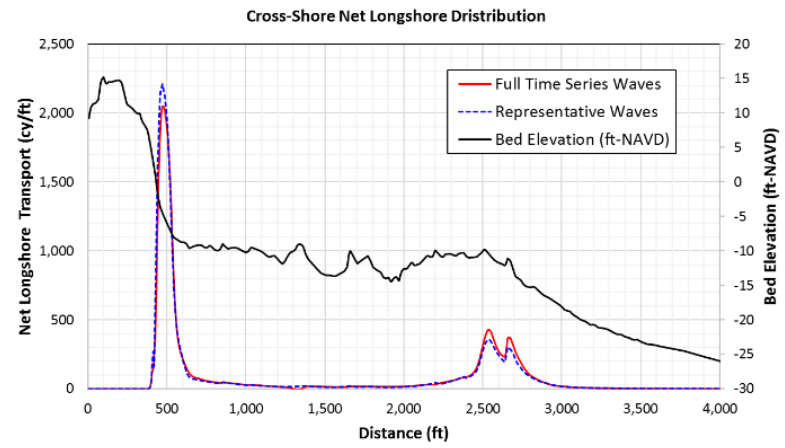

Figure 1 - Cross-shore distribution of longshore transport one year period after 2007 beach nourishment (July 1, 2007 - June 30, 2008)

Table 2 shows the SM model provided good estimates of the erosion (shoreline recession) at monuments $\mathrm{R}-35$, $\mathrm{T}$ $36, \mathrm{~T}-37, \mathrm{R}-38$, and T-40 where model results are within 6.7 meters of the measurements. The model overestimated erosion at monument R-34 and provided small accretion instead of erosion at monuments R-39 and $\mathrm{T}-41$. The SM model results are generally consistent with the observed erosion pattern from monuments R-34 to R38. The best agreement with measurement are from monuments R-35 to R-38 - the specific area where the model will be used to evaluate beach stabilization.

Table 2 - Measured and modeled mean high water shoreline onshore (negative) and offshore (positive) net movement for 2007 beach nourishment

\begin{tabular}{|c|c|c|c|}
\hline Monument & $\begin{array}{c}\text { Measured } \\
(\mathbf{m})\end{array}$ & $\begin{array}{c}\text { Modeled } \\
(\mathbf{m})\end{array}$ & $\begin{array}{c}\text { Difference } \\
(\mathbf{m})\end{array}$ \\
\hline R-34 & -78.9 & -120.1 & -41.1 \\
\hline R-35 & -33.2 & -39.9 & -6.7 \\
\hline T-36 & -26.5 & -26.8 & -0.3 \\
\hline T-37 & -10.1 & -13.1 & -3.0 \\
\hline R-38 & -8.5 & -11.6 & -3.0 \\
\hline R-39 & -11.3 & 16.5 & 27.7 \\
\hline T-40 & -8.5 & -4.3 & 4.3 \\
\hline T-41 & -8.8 & 4.6 & 13.4 \\
\hline
\end{tabular}

The discrepancies between the modeled and measured shoreline movement are deemed acceptable given the limitations in the available model input data - (a) there is 
no complete information on the sediment median size distribution throughout the project area and nearshore area and (b) the offshore waves and tides applied in the model are not from direct measurements but come from wave hindcasts and tide predictions. As the model will be mostly used to evaluate the effect of coastal structures on shoreline movement in the area south of monument R-34 and as the model provided good trends in the shoreline movement in the same area, the model is deemed useful to provide an evaluation of long-term shoreline movement due to various alternative placement of coastal structures for reducing beach erosion and sand retention.

\section{SHORELINE STABILIZATION SCHEMES}

This study compared the baseline "no structures" alternative to the coastal structures alternative (Figure 2) to evaluate the structures' effectiveness in reducing beach erosion. The no structure alternative included only beach nourishment in the project area. The coastal structures alternative included the same baseline beach nourishment and construction of five T-head groins (T1 - T5), a T-head weir (W6), and a breakwater (B7) approximately $480 \mathrm{~m}$ (T5), $550 \mathrm{~m}$, and $630 \mathrm{~m}$ south of the jetty, respectively.

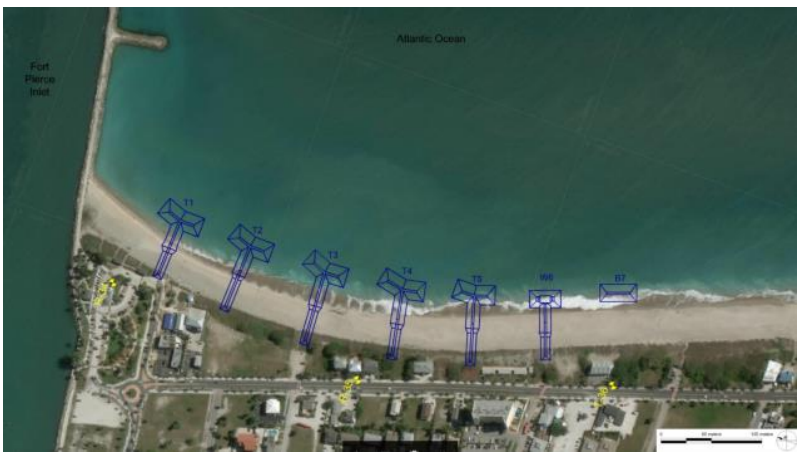

Figure 2 - T-head groins, T-head weir, and breakwater structures combined with beach nourishment for shoreline stabilization

\section{SHORELINE MORPHOLOGY MODELING}

This study applied the previously validated HD and SW models to provide the hydraulic conditions in the project area. Measured, hindcasted, or predicted data provided the conditions at the model boundaries, and measured sediment properties provided shoreline and nearshore area sediment descriptions. For faster model simulation, this study applied directionally decoupled parametric wave spectral formulation and quasi-stationary formulation of the SW and HD models' basic equations. The study excluded the effect of tidal flows along the inlet and nearshore areas as wave-generated currents mainly move beach fill at the project area. The calibrated LP model provided the multi-year longshore transport and the effective wave and tide conditions for normal and storm conditions.

The ST model used the HD and SW models' hydraulics results to estimate the suspended and bed load sediment transport in the nearshore area. The calibrated SM model calculated shoreline location after beach nourishment and construction of shoreline coastal structures. The SM model used a predefined cross-shore profile and integration of the change in sediment volume during each time step across the shore face to update the morphology according to the continuity equation for the shoreline. In the model simulation, the coastal structures were initially buried just underneath the beach nourishment and became either partially or fully emergent as the nourishment material erodes away from the structures' surrounding area.

\section{RESULTS OF ANALYSIS}

The modeled baseline "no structures" results compared very well with the field observed high erosion midway between monuments R-34 and R-35. Model results show a general pattern of shoreline retreat from monuments $R$ 34 to $\mathrm{T}-41$ - a pattern similar to observations a year after the 2007 beach nourishment (see Table 2). In general, the modeled baseline shoreline movement pattern is very similar to the general historical pattern observed in the project area - severe shoreline retreat at monument R-34, high erosion rates midway between monument R-34 and $R-35$, lesser shoreline retreat at monument R-35, and very small shoreline movement south of monument T-36 (relative to those at north of monument T-36). The similarity in the patterns of modeled and observed shoreline movements further validates the performance of the model.

Long-term model simulations that include normal tides and waves and storm conditions show (a) a baseline condition shoreline movement pattern similar to the general historical pattern observed in the project area, including accurately indicating the largest erosion rate and shoreline retreat along the first $0.7 \mathrm{~km}$ south of the jetty; and (b) the coastal structures alternative will retain beach fill longer, resulting in lower erosion rates from 0.8 to $6.4 \mathrm{~km}$ south of the jetty (Figure 3 ).
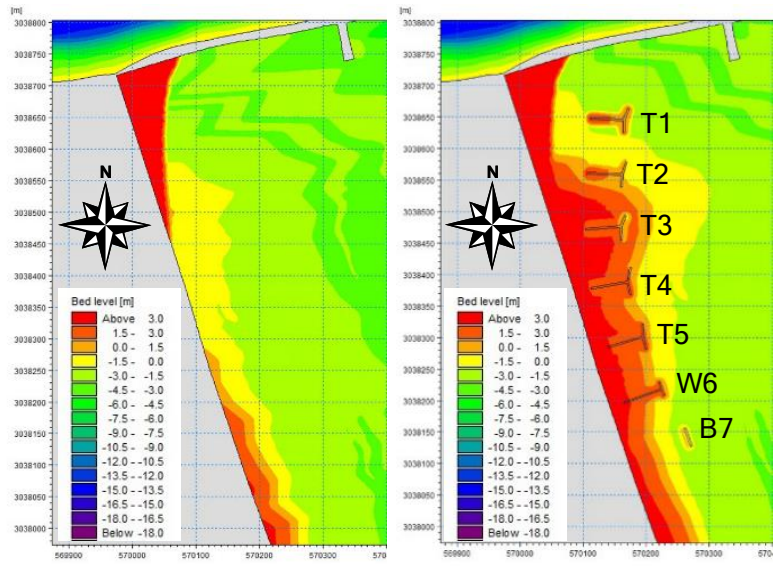

Figure 3 - Shoreline morphology after three years without coastal structures (left) and with coastal structures (right)

\section{CONCLUSIONS}

The MIKE21 Coupled Flexible Mesh (FM) finite-volume model - a two-dimensional coupling of the hydrodynamic $(\mathrm{HD})$, spectral wave $(\mathrm{SW})$, sand transport $(\mathrm{ST})$, and shoreline morphology (SM) models - simulated well the dynamic interdependence of surface elevation, flow velocity, waves, sediment transport, and beach evolution at the project site.

The coastal structures alternative feasibly extends the normal beach nourishment interval from the current two years to four years. Finding the optimal set of coastal structures for a more uniform erosion rate would require evaluation of different combinations of coastal structures and refining the locations and geometry of these structures. 